\title{
Creating Conservatism or Emancipating Subjects? On the Narrative of Islamic Observance in Egypt
}

\author{
Hania Sholkamy
}

\begin{abstract}
Women activists, politicians and policymakers including international development experts are seeking to harness the power of the divine. The rationale is simple: if people are driven by faith, then let us use faith to drive them towards social and political change. This article problematises the instrumentalisation of religion, arguing that there are many risks in pursuing this route as a way of addressing gendered injustices. It also calls for a different approach to disentangling women's engagement with religion as politics, as morality and as personal piety, using women's hair as a case in point. This is set against the discussion of the proliferations of religiosity that are shaping the subjectivities of men and women and changing the Egyptian polity.
\end{abstract}

Since the events of September 11, 2001, against the backdrop of two decades of the ascendance of global religious politics, urgent calls for the reinstatement of secularism have reached a crescendo that cannot be ignored. The most obvious target of these strident calls is Islam, particularly those practices and discourses within Islam that are suspected of fostering fundamentalism and militancy. It has become de rigueur for leftists and liberals alike to link the fate of democracy in the Muslim world with the institutionalization of secularism - both as a political doctrine and as a political ethic. (Mahmood 2006: 323)

The above quote expresses the confounding effect of politics on freedom and debate. In the article by Mahmood, scholars engaged in their scholarship are elided with a suspect report by a right-wing policy group in the USA (The Rand Foundation). The report recommends the support of modernist readings and interpretations of Muslim canonical texts, arguing that this 'safer' version of Islam better serves US interests and allies. Reform, liberalism and reflection all seem to be 'Western' privileges and Muslims who assume such projects are likewise cast as lackeys of a Western project! Such 'readings' of current debates on Islam invariably refer to women and the veil as an example (often the example) of the vagaries of secularism, of the oppression of religious norms, of the traditionalism of religious discourses or of the intolerance of liberal thought. Women are at the heart of literalist vs reformist interpretations of the holy Qur'an and at the crossroads of warring armies saying they will liberate them or feigning to fight on their behalf.

The animosity that is evident in the most scholarly and sophisticated of positions towards the 'other' makes for an unfolding story that may come to shape lives and destinies. It is too important to leave it to intellectuals cautious and concerned about their own ability to beat the other scholar! Ziba Mir-Hosseini has rightly noted the stale or déjà vu quality of these debates because the cards were thrown up in the air and have landed on various sides, thus cementing positions and positionalities. ${ }^{1}$ I should find no space for yet another contribution! But as a woman trained in anthropology and an Egyptian researcher, I still find un-theorised and underdocumented proliferations of religiosity that are

IDS Bulletin Volume 42 Number 1 January 2011 @ 2011 The Author. IDS Bulletin (? 2011 Institute of Development Studies Published by Blackwell Publishing Ltd, 9600 Garsington Road, Oxford OX4 2DQ, UK and 350 Main Street, Malden, MA 02148, USA 
shaping the subjectivities of men and women and changing the Egyptian polity, creating new realms of possibility and impossibility. My interest is in deceit and mis-appropriation, as much as it is in appropriating the right to engage as a concerned subject who rejects the vagaries of current taxonomies of religious and secular.

This article attempts to engage (as others often have) with the narrative of religion and gender justice by looking at the social implications of intellectual zealotry and essentialisation of Islam and of feminism. Mohanty (2003) has noted the monolithic construction of the Third World victim as woman by Western feminists. But Al-Ali (2000) has noted a similar process in Islamicist renderings of the West as 'other' (I am here referring to thousands of tracts, websites and articles written in the tradition of political Islam) in a similarly homogenising vein. Similarly, Mahmood's (2006) inclusion of all non-Islamists as secular and making secularism an identical experience and point of view for millions regardless of whether they profess to be Muslim or not and regardless of the traditions and positions that they adopt, suggests that secular has become a residual category. All parties are fighting over a righteous ground of analytical precision to explain religious revival and its various forms and formulas; a phenomenon that is political at times, personal at others and ultimately social in its manifestations.

Few can doubt the prevalence of religious observance of Egyptians or the depth of faith that men and women profess. Daily rituals and prayer, turns of speech, choice of dress, public interactions, private preferences are all deeply dyed with religion. Copts and Muslims seem to let their religion decide where they work, where they live, what they do, what they wear, and how to express themselves. While the importance of religion to identity and to social life is observable in other societies and countries, this article specifically focuses on these dynamics in Egypt, or more accurately, about the discourse of feminism and religion in Egypt.

Scholars and activists over the last two decades have questioned the Western credentials of feminism and claimed justice as a purpose and possibility that can be captured via religious routes. Religion provides women with an ethical framework and a moral foundation that recognises their rights as individuals and as a collective, albeit redefining equality in the process. The mosque movement in Egypt has empowered women to find dignity, companionship and comfort through piety and conformity to a religious ideal that challenges the less than perfect world around them. Moreover, by engaging with religion, Muslim women are able to redefine the tenets that have endowed Islam with an unnecessary bias for men; one which feminist scholars of Islam are certain is antithetical to the spirit and philosophy of our religion (see Mir-Hosseini, this IDS Bulletin).

Such serious engagements are however quite separate and distinct from the popularisation of religion as a veneer for growing conservatism that is antithetical to change and reflection. Restoring the principles of equality and justice upon which Islam was founded is not the same as using religious slogans, appearances and hegemonies to achieve political gains or affect policy changes. Religion as faith is all too often elided with religion as politics. Now politicians and policymakers, including international development experts, are seeking to harness the power of the divine. The rationale is simple: if people are driven by faith, then let us use faith to drive them towards social and political change.

The instrumentalisation of religion, and of Islam in particular, is worrying and problematic. The promotion of religion as a route to social justice may in the short term succeed but in the long term will make religion the arbitrator of politics and of social change. Movements for social justice who place religion as their ultimate reference and at the core of their politics would of course find no problem with such a prospect. But I beg to differ with this utilitarian view of religion.

In Egypt, researchers and activists seeking to introduce changes in attitudes and practices relating to women's rights and public health have sought to promote a religious approach that 'reveals' the progressive potential nascent in Islam. The Khol' law, which gives women the right to initiate divorce, rests on a prophetic tradition that has been long known and ignored by scholars, in which a woman asked the prophet ('peace be upon him') how to end her unhappy marriage. She was advised to return her bride- 
price to her husband as the only pre-condition for divorce. Women's rights advocates led by national women's machineries such as the National Council for Women in Egypt invoked this incident to argue for a change in divorce laws. They were successful.

Recent efforts to pass a child's rights law in Egypt that prohibits corporeal punishment, criminalises female genital mutilation and explicitly bans early marriage for girls has also invoked Qur'anic and prophetic positions and evidence. However, these efforts have faced harsh opposition in parliament specifically from the independents (Islamist) and other opposition who are citing their own interpretations of religious texts to sanction female genital mutilation and early marriage as practices that ensure female sexual modesty. And these are insistent on the parental right to discipline children, even if using physical censure to ensure that children do not stray into delinquency. Whose interpretation gets sanctioned is a question of politics not of faith (El-Masry El-Youm 2008). Using religion as the pathway to gender justice is not a smooth strategy. It can work well but may cause stumbling when the pathway becomes more important than the destination.

These forces have created a religious normativity that is distinct from the appropriation of faith as politics or as a liberation project. Egypt is ruled by a conservatism that is dressed in religious garb. In this article, I see two very separate spaces where questions of gender and religion intersect. One is a liberating movement that is trying to assert a Muslim subjectivity that enjoys gender equality by advocating progressive revisions to religious laws and texts. This is a difficult project that has gained recognition but the proponents of which in Egypt have suffered ridicule and persecution (scholars such as Nasr Hamid Abu-Zeid, Abdel Mo'ty Bayoumi or Zeinab Radwan in Egypt). The other is the hegemony of religious images, symbols and practices in social life, particularly the social life of women. The headscarf and veil have become the national dress for women, while prayer marks on men's foreheads have emerged as symbols of their piety. In our everyday language, we continuously invoke the names of God and the prophet. All types of religious conformity are strongly encouraged and the arbitrators of social and political actions are religious scholars. This pervasive piety has attracted the attentions of feminists and of activists who seek to harness the power of piety to innovate and lift social burdens of gender oppression. Religious texts are used to substantiate women's rights and freedoms.

Female genital mutilation, birth control, sexual rights and rights to property and mobility, we are often reminded, are addressed by Islamic codes that favour women. Unfortunately, satellite channels, popular books and even some textbooks used in seminaries are not in accordance with this progressive interpretation. They are spreading a very different rendition of religious teachings.

When feminists try to use religion, they are also promoting the idea that we should make our life decisions in accordance with standardised religious teachings rather than by appealing to a sense of equity or justice. This utilitarian approach may win some people over but it may precipitate a bigger loss; that is the loss of independent reason and the loss of faith as an absolute not instrumental passion. This is not to espouse a Western rationalist approach that assumes religion to be a matter of private concern and rejects the idiom of religion as a vehicle for collective action. Actually, Sufism, a purely religious philosophy that is indigenous to Islam, has rejected the external trappings of the practice of faith as secondary to the personal and continuous struggle to attain enlightenment and true faith.

The pursuit of a language of engagement with Muslims inside and outside Western societies is evident in confusions around feminisms, Islam and feminist Muslims. Feminism has had a very limited purchase among grassroots movements in Muslim countries, while Islamic political activism is widespread and popular. Feminist Muslims are an often-misunderstood group; these are women and men who believe in social justice, who adhere to Islam as a faith but who do not use it as an identity qualifier. They are a group that are sometimes dismissed as out of touch; Western, secularists. Then there are those who are activists politically engaged in local and international politics who use their faith as an idiom of representation. In some cases, these groups are countering patriarchal ideological trends within religious thought and in others, they are not. Activists who are seeking to establish the legitimacy of gender justice on religious grounds 
may be trying to realise feminist gains by appealing to religious sentiments or they may further the notion that choices have to be religiously recommended and sanctioned.

\section{Methodological mountains}

To understand the instrumentalisation of religion as a phenomenon that is distinct from religious revival or reform we need better analytical and research tools. Ultimately, there is an epistemological challenge to understanding religion as action and as faith. The way we know that religion is strong or present requires its own revisions.

There are two difficulties in discussing religious observances and their meanings. The first concerns frames of reference and the second is about evidence and empiricism. These two 'mountains' define the topography of the debate and precipitate an almost adversarial divide.

The frames of reference of Western academia are obstinately Western. The word reform for example must necessarily reference Western reforms of Christianity and the rise of the secular state as if that in itself was not a historical process that had its own contingencies, hesitations and mistakes. There were many 'Christianities' as there has always been a living and lived tradition and intellectual traditions and forces called 'Islam' (Al-Azmeh 2009: 1). The strictures of Western thought litter these writings. Mahmood (2006) refers to autonomous reflection as 'Kantian'. This is no doubt an accurate and perhaps eloquent qualifier, but one that may sound very strange to those steeped in other philosophical traditions who may reference the Mu'tazilites or even the text of the Qur'an itself that repeatedly addresses al insan (the human being) and her/his aql (rational faculty) and invites those thus addressed to reflect and ponder.

The problem of frames of reference and interpretive signposts is when scholars impose meaning from one tradition on the observable actions and choices of another. The separation for example that Asad assumes between state and society does not really resonate with the meaning of 'dawla' and 'mogtama' that I understand in Egypt (Asad 1980). This reference to sovereign power as the act by which the state shapes religion and deprives society the ability or agency to do so, assumes that state and society are distinct; always separate and delineated by some political process. Neither category is stable, with kinship, class, ethnicity and ideology shaping both. Indeed to reference the meaning of society that Asad insinuates, we have to add the epithet 'madany' or 'civil' as one does in English but in Arabic madany refers to a condition that is opposite to military.

Secularism sometimes seems to be an analytical invention much affected by Western philosophical formation. It is important to tag some empirical evidence and nuances to the ghost of secularism. I will look here at Egypt in particular. The pre-Sadat period in Egyptian history was one in which the hegemonic symbols that shaped identity derived from a Third World liberation moment, from a modernism, a middleclass victory and a socialist ethic. This is not to suggest that such conceptions are necessarily true, however it is to assert that the symbols of identity and the way of being in the world that derived from these traditions were not antireligion but were extra-religious! Al-Azmeh notes the alliance between President Nasser and the Al-Azhar mosque (2009). Nasser often spoke to the nation from Al-Azhar, the foremost Sunni centre of learning, jurisprudence and scholarship. There was no doubt that the Nasserite regime was Muslim, comfortable in its faith but not ruled by the symbols of certain renditions of faith. It is only after the 1967 defeat that Sheikh Sha'rawy among others, blamed the lack of public religious observance on the part of the Egyptians for their military humiliation. He famously noted that he had gone down on his knees to thank God for the defeat, as this would goad Egyptians to mimic the religiosity of the Israeli soldiers and state. The so-called secular post-colonial state was never an Egyptian one in the sense that there has never been a separation of religion and state, for example there was never a shortage of religious content in the media, no president came to power who did not publicly and consistently use religious symbols, signs, engage in promoting religious institutions, frames of reference and presence, and there has hardly ever been an absence of religious scholarship, stewardship or influence over Egypt.

The problem of frames of reference has produced an almost sclerotic understanding of what is religion, and what it is not. The second 
problem is that of evidence. How do you describe the acts of faith that are public, political, private, personal, reflexive, rhetorical, analytical and polemical all in one go and as one thing? Are all acts of observance similar enough to have similar meaning? I would like to give an example from recent interviews conducted in Egypt concerning motivations for veiling and un-veiling.

\section{Hair}

Religiosity is more easily understood as a political or social decision/act than as a personal one.

Social sciences inadequately analyse the motivations of individuals, often aiming to frame acts in socioeconomic or ideological structures. Thus the act of veiling, for example, for Muslim women becomes a singular act that has a restricted implicational meaning and significance and the women who perform this act are homogenised as either willing believers or less willing conformists. Hair covering is such an act/decision. Although a practice that has cultural origins, it has become religiously sanctioned and promoted as an aspect of an overall modest Muslim femininity since the 1970s. Here, an analysis of the motivations for veiling as expressed by a small number of middleclass Cairene women who 'chose' to cover their hair in their middle years is presented. These middle-class and well-educated, well-off women shared their reflections with the author on the construction of their femininity and identity as Muslim women. The conversations with these women are not intended to be representative of the opinions of millions of veiled and veiling women, nor are they meant to 'explain' why women conform to religious structures and strictures. The article is investigating the significance of motivation to the meaning of the act itself. If women have different objectives and reasons for veiling, does that not question the meaning of hair covering itself?

The symbolism of hair through covering, shaving, growing or cutting is a universally significant dimension of gender discourses. Shaving hair is an act of mourning for some women; bobbing hair has been an act of liberation and empowerment for others, and veiling is an act of devotion for millions of Muslims. Anthropologists of Islam have considered the veil as a dimension of piety and as an act of self-identification as a Muslim. These conversations investigate the agency of adult women who have decided to cover their hair voluntarily and that of women who have not done so. In obeying the edicts of Islam to veil, women are engaging in a choice and an interpretive act that may be motivated by more than simple religiosity. By not covering their hair, they may not necessarily be expressing apposition to piety or to a modern religious sensibility. El-Hijab and al-Sofour are expressions of class, and of a relationship with the divine, mediated by both the seen and the un-seen.

\section{A nod to the literature}

The anthropology of locks and tresses has contemplated the symbolic meaning of hair verifying associations with sexuality, pollution and control (or lack thereof). Leach's essay on 'magical hair', written in 1958, described the symbolism of hair in communicating individual and collective ideas about the social world. Leach differentiated between public symbolic behaviour and private ritual behaviour, identifying the potency of the first as a communication medium and the second, as a tool of personal/psychological formation and identification (Leach 1958). Anthropologists have further investigated the meaning, symbolism and power of hair in the fields of asceticism. Obeyesekere (1981) confirmed the interconnectedness of individual and public symbols thus rejecting the differentiations of Leach. ${ }^{2}$ Others have attempted frameworks for a universal understanding of hair symbolism (Synott 1993) and produced riveting ethnographies on hair, sexuality and religions.

In the past two decades, scholars studying Muslim societies have neglected hair in favour of the veil. The main thrust of this rich literature is on why Muslims veil, why the French do not want them to veil, and the symbolism, tokenism, and the power of covered heads. Ingrid PflugerSchindlbeck has written on hair symbolism in Muslim societies, with a special focus on the ethnography of Turkey. She describes practices and beliefs that concern female, male and children's hair, positing an analysis that fuses 'social, Islamic institutional definitions (the relation human-society) and religious concepts of the human body (the relation between human and God). Only then' she goes on to say, 'does the handling of hair lose its irrationality and it is possible for anthropology to rid the seemingly strange behaviour of a defined other of its exoticism' (Pfluger-Schindlbeck 2006: 84). 
This article grasps this suggestion of fusion and considers the symbolic and practical language of female head hair in Cairo. Why? Because the native in me is frustrated by anthropology in both its integral and critical revisionist forms and the inclination of the discipline to encourage intellectual production that privileges the discipline's own theoretical predilections over the understanding of social life and the recognition of rapid change on the ground. Every revision seems to recreate the distance and othering practices of the past. Thus veiling has become the weapon of choice in the gender discourse of anthropologists. The research that abounds has projected this polyvalent symbol as an expression of submission, political assertiveness, tradition, modernity, protest and conformity. More recently, the covering of head hair and items of Islamic dress (a label that I resent as a Muslim for its exclusions) have been projected as symbols of an emerging piety that is re-crafting the terms of engagement between women and society through the idiom of religiosity and what it means to be a Muslim in the world today.

\section{Fardd}

With the years, the benchmarks of religiosity have quickly risen to new heights that are ever harder to attain. Covering hair is the minimum of modest dress. Women who merely cover their hair like Nada, one of the women I conversed with, are considered by some as not veiled but are called modest (multazima). The turban or veil tied back coupled with long sleeves and loose clothes that do not necessarily extend to the floor are dismissed as a deficient dress code and were described in some of my conversations as the basic way women should dress to show that they are respectable and serious. The khimar, which is the loose (no waistline) long dress in dark colours, coupled with a veil that covers the front, is the norm or what my interlocutors would deem a hijab. Then there is the niqab which is loose, black and entails covering the face. Needless to say in this race to the pinnacles of modesty, the niqab is said to be the only correct form of Islamic dress, by the women who wear it.

A few years ago, the Egyptian Minister of Culture made a rather silly remark to a journalist 'offrecord' about hair being the crowning glory of a women's beauty. Then he expressed his astonishment at the pace and prevalence with which Egyptian women are veiling. The journalist who worked for an independent paper published the interview and not only included these remarks but used them as the headlines for the whole page. They were also emphasised with a mention on the front page of the newspaper. Public outrage and a parliamentary uproar ensued. Thousands of women took to the streets in protest against this offence to their choice and faith. Covering the head is a Fardd not a choice. The minister, already disliked because of his long stay in government (over 20 years) and his widely acknowledged proximity to the Presidential family, was made to appear in parliament and face a slue of humiliations from the ruling National Democratic Party, as well as from those representatives who derived from an Islamist platform. He apologised publicly and in his own defence, said that nearly all the women in his ministry are veiled, as is his own sister. In the end, the dust settled and the press moved on to other stories. But the oft-repeated shift from choice to obligation to cover one's hair had now been established in parliament and on the street and has brought together the government and the opposition, who in unison confirmed that head hair is haram (in prohibition of religion).

My conversations took this benchmark and its public implications as a starting point. Three women had veiled and un-veiled. They had felt that covering their hair was hypocritical. 'It made no difference to my faith, piety or my sense of being a Muslim. I am no less moral then the women I know who are veiled', said Sherine. 'I didn't like the bullying and the pressure that I got from other women who I met in Qur'an sessions', said Samia. 'The minute I veiled they started telling me that I was not veiled enough. A few were compassionate, saying it was a good step but I did not like the pressure and their intervention. My hair and my faith are something between me and God and my husband felt that I should do what I feel comfortable with', she added.

In conversation with women who have covered their hair and others who did so and chose to uncover it again, it was evident that there was a marked distinction between morality and piety. There was also a clear class dimension to these positions.

Of the women with whom I have had these conversations, there were those who felt that 
hair is the crowning glory of a woman's beauty and 'that is why God has asked us to cover it'. They said that the Qur'an was unequivocal about the obligation to cover hair because Muslim women are required to keep their beauty guarded and safe from the transgressing gaze of the public. Two women interviewed who are less well-off than other respondents said that there is no question, no possibility of not covering their hair. They would not be able to go out, to work, or to show themselves in the street. It is the rich who can walk around with coiffed hair and show it off. In their parts of the city both agreed, noone does that anymore. But on the other hand, one woman asked: Why would a Muslim woman show her hair anyway? - It is now the practice, it is the norm, it is an obligation and it is a way to distinguish Muslims from non-Muslims.

All the better-off veiled women who participated in my conversations covered their hair as adults and did so as a sign of deep devotion to God. For them hair, again coiffed, dyed, long and well groomed, was a sign of their status and an aspect of a public persona that signified a certain way of life, level of education and ease of life.

The decision to cover can be motivated by a number of externalities. One motivation can be seen in the remark, 'my husband wanted me to [veil] after we performed the pilgrimage'.

Another line of reasoning concerns crisis, stress, and the sense of grace and peace that came with the decision to keep hair covered. Thus women have de-linked morality from the interpretations of piety imposed by the public discourse on hair and veiling. Perhaps in shy self-defence or as a last gasp retort against new pressures for regimented piety, some are marking other avenues to God than those selected by organised religious movements. Moreover, those who have seemingly followed the path defined by this new hegemony may have personal reasons that stray from the narrow one defined by organised religious sensibility.

A sense of power and an expression of class identity are derived from choices of dress and calibrated modesty. Women have covered their hair as an act of gratitude to God, as an act of protection from the wrath of God, and as an act of adapting to the will of God. Motivations reflect the nature of the relationship between women and the divine and a perception/or sentiment about the meaning and significance of female hair. This relationship is always ideologically mediated. Anthropology has focused on the mediations of organised religion but has to a lesser extent, addressed the deviance and reinterpretations and implementations that are expressed in a mundane, less politicised context.

There are so many different meanings to similar acts of observance. The joy of collective action such as group prayers and Qur'an readings are valid reasons for religious observance but so is the desire by women to attain religious sanctity and practice one's faith; and equally important, is the desire to negate class distinctions and differentiations. Motivations are multiple and equally valid. Thus, the acts of observance are distinct from the reading of them as signs of a political choice.

\section{Whose faith? Islam is many solutions}

Faith-based social movements do not have a monopoly on faith. They have a political programme that should be valued on its merits and on its promise to deliver equity and justice. A progressive or liberating agenda for women could have a religious or other moral frame of reference. Women have a right to choose a religious identity as the public one with which they engage in politics. But imposing this choice on others who wear a different 'hat/veil' is another thing altogether.

The right to choose our politics is one all women engaged in any struggle should safeguard and promote. It would be illusionary to assume that religious authority is 'pure' or un-mediated by power. This power is a masculinist one that instrumentalises the engagement of women. Here again, I am not referring to the project of returning to ijtihad (reinterpretation of the sacred texts) as informed by justice and equity, but the authority that prevents young girls from 'removing' veils or that enables government bureaucrats to enforce religious observances, exclude Copts and impose a Sunni middle-class morality that is often backed by power and money.

People in Egypt may agree that Islam is the Solution but differ on who has the mandate and mission to implement that solution and assume the mantle of Islam. Islamist political movements have had the savvy ability to occupy this territory as self-proclaimed representatives. 
Others who do not employ religion as a political creed have never denied that they are Muslims but they may be rightly wary of using their faith as a vehicle for advancing social agendas.

In pursuit of this agenda, finding a 'Safe Islam', Western interventions are promoting an instrumentalist approach that favours conservatism and religiosity as a route to Eastern minds and hearts. In the midst of so many passions, the distinctions between faith and politics can get lost, the assumption that all things religious are preferable to those that are not may become a hegemony, and so the authenticity and power of social justice as a cause is collapsed into a promotion of politics as a signifier of faith.

What we have in Egypt is a victory for conservatism, not of Islamism. Coptic social life mirrors Muslim social life. Entrenchments of church and mosque authority are all around us. But what about the consumption of these symbols? In the absence of different traditions that individuals, particularly youth, can reference to construct identity, collective and gendered, and practice agency, religion provides succour, security, and spiritual fulfilment. One of the deceits of an analytical project that is imposing a religious straitjacket is to negate the possibility of faith in the absence of a religious political commitment and identity. The creation of false dichotomies between religious and secular identities has failed women themselves.

Analysts have tried to salvage the right to religious identity from the fall-out of colonialisms and the mutations to agency and identity that have resulted from invasion and imperialism (Asad 1980; Al-Naim 1990; Said 1979). They have un-masked Orientalism's ability to create fictitious oppositions of the religious and the secular, the Eastern and the Western, the old and the new, the conservative and the liberal, the free and the oppressed and the myriad other polarities that have cast Islam as a force that is antithetical to change and progress. Thanks to these writers, we can now transcend this unfortunate state of analytical confusion and move our thinking ahead. It would be a shame to linger on the travesty of Western vandalism of Islam's heritage, followers and tenets. Unfortunately, we seem not to be able to move our thinking beyond historical mistakes.

My essay is not about faith-based feminism, but is a commentary on faith-based populism and its allure and attraction to activists and analysts. It is difficult to resist this particular temptation, for who can afford to lose the crowd or resist popularity? The nuanced argument made by MirHosseini (this IDS Bulletin) notes that both feminism and Islam need to be un-packed and understood in terms of their contexts and actions (Mir-Hosseini 1990). Feminism is prone to 'unpacking', as it remains, as she notes, an epistemological project that inspires critique and contemplation. Islam as faith is also a profound ontological and epistemological framework but when used as an instrument to affect political change, it is 'packed' and bundled into a simple, common and homogenised package that does not invite reflection or review. It is this rendition of institutionalised religion that I urge feminists and gender activists to avoid.

This article is, then, not about secular vs religious feminism. It is about the dangers of instrumentalisation and its consequences. I note that enlightenment is not 'Western' and justice is not the preserve of a culture. I state that patriarchy can adjust to the power of the sacred, or the push of the profane. I believe that faith can inspire us collectively, and not just condition us as individuals, but that faith offers broad outlines that are distinct from their specific, historical and political interpretations. Finally, I think that peoples and cultures are socially and historically constituted but that any ideology that aims to magnify differences between sexes, locations, ethnicities or histories so as to exercise power or privilege and precipitate a sense of specificity or distinction, is a mistaken one, and is certainly not friendly to feminism - the moral project with which I identify. 


\section{Notes}

1 Presentation and comments at the Institute of Development Studies (IDS) workshop 21-22 September, 2010.

\section{References}

Al-Ali, Nadje (2000) Secularism, Gender and the State in the Middle East: The Egyptian Women's Movement, Cambridge: Cambridge University Press

Al-Azmeh, Aziz (2009) Islams and Modernities, London: Verso

Al-Naim, Abdullahi Ahmed (1990) Toward an Islamic Reformation: Civil Liberties, Human Rights, and International Law, Syracuse: Syracuse University Press

Asad, Muhammad (1980) Principles of the State and Government in Islam, Gibraltar: Dar al-Andalus

El-Masry El-Youm (2008) Newspaper, 5 March: 1

Leach, Edmund (1958) 'Magical Hair' (Curl Bequest Essay 1957), Journal of the Royal Anthropological Institute 8.2: 147-64

Mahmood, Saba (2006) 'Secularism, Hermaneutics and Empire: The Politics of Islamic Reformation', Public Culture 18.2: 323-47
2 This interconnectedness is illustrated by veiled women feeling at ease when covering their hair and saying that this is how a natural woman should be in a public space.

Mir-Hosseini, Ziba (1990) Islam and Gender: The Religious Debate in Contemporary Iran, Princeton: Princeton University Press

Mohanty, Chandra T (2003) Feminism without Borders: Decolonizing Theory, Practicing Solidarity, Durham: Duke University Press

Obeyesekere, Gananath (1981) Medusa's Hair: An Essay on Personal Symbols and Religious Experience, Chicago: University of Chicago Press

Pfluger-Schindlbeck, Ingrid (2006) 'On the Symbolism of Hair in Islamic Societies: An Analysis of Approaches', Anthropology of the Middle East 1.2: 72-88

Said, Edward (1979) Orientalism, New York: Vintage

Synott, Anthony (1993) The Body Social: Symbolism, Self and Society, London: Routledge 